\title{
SURFACE ROUGHNESS AND GRAIN SIZE CHARACTERIZATION OF ANNEALING TEMPERATURE EFFECT FOR GROWTH GALLIUM AND TANTALUM DOPED $\mathrm{Ba}_{0.5} \mathrm{Sr}_{0.5} \mathrm{TiO}_{3}$ THIN FILM
}

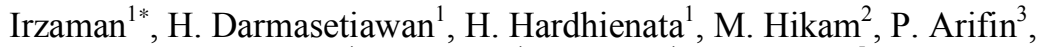 \\ S. N. Jusoh ${ }^{4}$, S. Taking ${ }^{4}$, Z. Jamal ${ }^{4}$, M. A. Idris ${ }^{5}$ \\ 'Department of Physics, FMIPA Bogor Agricultural Unversity (BAU), \\ BAU Campus Darmaga Gedung Wing S Bogor, Indonesia - 16680 \\ ${ }^{2}$ Department of Physics, FMIPA UI, UI Campus Depok, Indonesia - 17000 \\ ${ }^{3}$ Department of Physics, FMIPA ITB, Jalan Ganesa 10 Bandung, Indonesia - 40132 \\ ${ }^{4}$ School of Microelectronic Engineering, Universiti Malaysia Perlis, \\ Jalan Bukit Lagi, 01000 Kangar Perlis, Malaysia. \\ ${ }^{5}$ School of Material Engineering, Universiti Malaysia Perlis, \\ Jalan Bukit Lagi, 01000 Kangar Perlis, Malaysia.
}

Received 9 November 2008; Received in revised form 24 August 2009; Accepted 25 August 2009

\begin{abstract}
SURFACE ROUGHNESS AND GRAIN SIZE CHARACTERIZATION OF ANNEALING TEMPERATURE EFFECT FOR GROWTH GALLIUM AND TANTALUM DOPED $\mathrm{Ba}_{0.5} \mathbf{S r}_{0.5} \mathrm{TiO}_{3}$ THIN FILM. Thin films $10 \%$ gallium oxide doped barium strontium titanate (BGST) and $10 \%$ tantalum oxide doped barium strontium titanate (BTST) were prepared on p-type Si (100) substrates using chemical solution deposition (CSD) method with $1.00 \mathrm{M}$ precursor. The films were deposited by spin coating method with spinning speed at $3000 \mathrm{rpm}$ for 30 seconds. The post deposition annealing of the films were carried out in a furnace at $200^{\circ} \mathrm{C}, 240^{\circ} \mathrm{C}, 280^{\circ} \mathrm{C}$ (low temperature) for 1 hour in oxygen gas atmosphere. The surface roughness and grain size analysis of the grown thin films are described by atomic force microscope (AFM) method at $5000 \mathrm{~nm} \times 5000 \mathrm{~nm}$ area. The rms surface roughness BGST thin films at $5000 \mathrm{~nm} \times 5000 \mathrm{~nm}$ area are $0.632 \mathrm{~nm}, 0.564 \mathrm{~nm}$, $0.487 \mathrm{~nm}$ for temperature $200^{\circ} \mathrm{C}, 240^{\circ} \mathrm{C}, 280^{\circ} \mathrm{C}$, respectively, whereas the grain size (mean diameter) are $238.4 \mathrm{~nm}, 219.0 \mathrm{~nm}, 185.1 \mathrm{~nm}$ for temperature $200^{\circ} \mathrm{C}, 240^{\circ} \mathrm{C}, 280^{\circ} \mathrm{C}$, respectively. In fact, to increase annealing temperature from $200^{\circ} \mathrm{C}$ to $280^{\circ} \mathrm{C}$ would result in decreasing the rms roughness and grain size. Therefore, rms roughness and grain size would have the strong correlation annealing temperature.
\end{abstract}

Keywords: BGST, BTST, thin films, CSD method, AFM, roughness, grain size.

() 2009 Atom Indonesia. All rights reserved.

\section{INTRODUCTION}

Thin $\mathrm{BaTiO}_{3}$ (BT) and $\mathrm{Ba}_{0.5} \mathrm{Sr}_{0.5} \mathrm{TiO}_{3}$ (BST) is a well known dielectric material and has been attractive for the applications such as capacitors and high density dynamic random access memory (DRAM) due to its high dielectric constant and high capacity of charge storage [1,2] and solar cell [3].

* Corresponding author.

E-mail addresses: irzaman@yahoo.com (Irzaman) 
BT and BST films can be formed by various methods, such as chemical solution deposition (CSD) $[1,2,4]$, metal organic chemical vapor deposition (MOCVD) [5-7], rf sputtering [8-13] and Pulsed Laser Ablation Deposition (PLAD) [14]. CSD Method is of particular interest because of its good control of stoichiometry, ease of fabrication and low temperature synthesis. It is relatively new and requires a greater understanding to optimize film quality. Crystallization mechanisms in CSD-derived thin films are different from phenomena associated with vapor phase epitaxy. It was reported that CSD derived thermodinamically stable.

Gallium oxide doped barium strontium titanate and tantalum oxide doped barium titanate have been of immense interest in the use of ferroelectric solar cell (FSC) [3]. The roughness and grain size properties of the materials can be tailored by varying the concentration of the dopant and annealing temperature. Since the sensor performance significantly depends on these properties, the FSC performance can then be optimized.

The surface roughness and grain size analysis of the grown thin films are analysed by atomic force microscope (AFM) method at nanoscale area. Instead of tunneling current, an AFM detects interatomic forces that occur between a cantilever probe tip and a sample. Normal imaging forces are in the 1 - 50 nanonewton range and cantilever deflections of less than $0.1 \mathrm{~nm}$ can be detected (nanoscale) [15-21].

In this paper we report on the fabrication of $10 \%$ gallium oxide doped barium strontium titanate and $10 \%$ tantalum oxide doped barium strontium titanate thin films by CSD with $1.00 \mathrm{M}$ precursor. Using $10 \%$ gallium oxide and $10 \%$ tantalum oxide doped barium strontium titanate thin films by CSD, can be increase the homogeneous performance of The roughness and grain size. The roughness and grain size properties of the grown films related to the dopant gallium oxide, tantalum oxide and annealing temperature are described.

\section{MATERIALS AND METHODS}

Procedural BGST thin films were fabricated by CSD methods using $0.160 \mathrm{~g}$ barium acetic $\left[\mathrm{Ba}\left(\mathrm{CH}_{3} \mathrm{COO}\right)_{2}, 99 \%\right.$ purity $]+0.131 \mathrm{~g}$ strontium acetic $\left[\mathrm{Sr}\left(\mathrm{CH}_{3} \mathrm{COO}\right)_{2}, 99 \%\right.$ purity] $+0.355 \mathrm{~g}$ titanium isopropoxide $\left[\mathrm{Ti}\left(\mathrm{C}_{12} \mathrm{O}_{4} \mathrm{H}_{28}\right), 99.999 \%\right.$ purity $]+0.060 \mathrm{~g}$ gallium oxide as precursor in $1.25 \mathrm{ml}$ 2-methoxyethanol $\left[\mathrm{H}_{3} \mathrm{COOCH}_{2} \mathrm{CH}_{2} \mathrm{OH}, 99.9 \%\right.$ and using $0.160 \mathrm{~g}$ barium acetic $\left[\mathrm{Ba}\left(\mathrm{CH}_{3} \mathrm{COO}\right)_{2}, 99 \%\right.$ purity $]+0.131 \mathrm{~g}$ strontium acetic $\left[\mathrm{Sr}\left(\mathrm{CH}_{3} \mathrm{COO}\right)_{2}, 99 \%\right.$ purity $]+0.355 \mathrm{~g}$ titanium isopropoxide $\left[\mathrm{Ti}\left(\mathrm{C}_{12} \mathrm{O}_{4} \mathrm{H}_{28}\right)\right.$, $99.999 \%$ purity] $+0.060 \mathrm{~g}$ tantalum oxide as precursor in $1.25 \mathrm{ml}$ 2-methoxyethanol $\left[\mathrm{H}_{3} \mathrm{COOCH}_{2} \mathrm{CH}_{2} \mathrm{OH}, 99.9 \%\right]$ were used as solvent was introduced under mixing by Ultrasonic at 2 hours. A clear liquid resulted. After 20 minutes of standing at room temperature, this solution acquired a milky appearance. The cloudy appearance disappeared. It contained 
equivalent $1.00 \mathrm{M}$ BGST $10 \%$ and BTST $10 \%$. After 2 hours of aging, that solution was spin coated on $10 \mathrm{~mm}$ x $10 \mathrm{~mm}$-type Si (100) substrates, with spinning speed at $3000 \mathrm{rpm}$ for 30 seconds. The post deposition annealing of the films was carried out in a Furnace Model Nabertherm Type 27 at $200^{\circ} \mathrm{C}$, $240^{\circ} \mathrm{C}, 280^{\circ} \mathrm{C}$ (low temperature) for 1 hour in an oxygen atmosphere. The surface roughness and grain size analysis of the grown thin films are described by atomic force microscope (AFM) method at $5000 \mathrm{~nm}$ x $5000 \mathrm{~nm}$ area at room temperature in School of Microelectronic Engineering, Universiti Malaysia Perlis, Jalan Bukit Lagi, 01000 Kangar Perlis, Malaysia.

\section{RESULTS AND DISCUSSION}

The effect of growth temperature, gallium and tantalum dopant concentration on the surface morphology were carried out by using AFM images, respectively. Figure 1 - 9 shows surface analysis, grain size, 3 dimension using AFM method for annealing temperature at $200^{\circ} \mathrm{C}$ of $5000 \mathrm{~nm} \times 5000 \mathrm{~nm}$ area for BST, BGST, BTST thin films varying annealing temperature $\left(200^{\circ} \mathrm{C}, 240^{\circ} \mathrm{C}, 280^{\circ} \mathrm{C}\right)$. Whereas, Figure $10-12$ shows surface roughness, mean grain size, grain diameter varying annealing temperature, dopant gallium and tantalum. The rms surface roughness for BST thin films at $5000 \mathrm{~nm} \times 5000 \mathrm{~nm}$ area are $10.50 \mathrm{~nm}, 0.6324 \mathrm{~nm}, 0.2202 \mathrm{~nm}$ for temperature $200^{\circ} \mathrm{C}, 240^{\circ} \mathrm{C}, 280^{\circ} \mathrm{C}$, respectively, whereas the grain size (mean diameter) are $1,046 \mathrm{~nm}, 238.4 \mathrm{~nm}, 141.3 \mathrm{~nm}$ for temperature $200^{\circ} \mathrm{C}$, $240^{\circ} \mathrm{C}, 280^{\circ} \mathrm{C}$, respectively. The rms surface roughness for BGST thin films at $5000 \mathrm{~nm} \mathrm{x} 5000 \mathrm{~nm}$ area are $0.632 \mathrm{~nm}, 0.564 \mathrm{~nm}, 0.487 \mathrm{~nm}$ for temperature $200^{\circ} \mathrm{C}, 240^{\circ} \mathrm{C}, 280^{\circ} \mathrm{C}$, respectively, whereas the grain size (mean diameter) are $238.4 \mathrm{~nm}, 219.0 \mathrm{~nm}, 185.1 \mathrm{~nm}$ for temperature $200^{\circ} \mathrm{C}, 240^{\circ} \mathrm{C}$, $280^{\circ} \mathrm{C}$, respectively. The rms surface roughness for BTST thin films at $5000 \mathrm{~nm} \times 5000 \mathrm{~nm}$ area are $1.087 \mathrm{~nm}, 0.4870 \mathrm{~nm}, 0.2317 \mathrm{~nm}$ for temperature $200^{\circ} \mathrm{C}, 240^{\circ} \mathrm{C}, 280^{\circ} \mathrm{C}$, respectively, whereas the grain size (mean diameter) are $158.7 \mathrm{~nm}, 291.1 \mathrm{~nm}, 396.7 \mathrm{~nm}$ for temperature $200^{\circ} \mathrm{C}$, $240^{\circ} \mathrm{C}, 280^{\circ} \mathrm{C}$, respectively. In fact, to increase annealing temperature from $200^{\circ} \mathrm{C}$ to $280^{\circ} \mathrm{C}$ dominant would result in decreasing the rms roughness and grain size. Therefore, rms roughness and grain size would have the strong correlation annealing temperature. This suggests the primary mechanism for the decay of thermodynamically unstable BST compound in gallium or tantalum desorption and phase rearrangement of the surface in the absence of reactive oxygen environment during annealing temperature. This thermodynamic tendency for oxygen vacancy formation would lead to structural degradation of the films. By changing the temperature to the optimum growth temperature $\left(280^{\circ} \mathrm{C}\right)$, the spots began to shrink indicating that the formation of second phase precipitate can be suppressed at this growth temperature (Figures 3, 6, 9, 10, 11, 12). 
BST

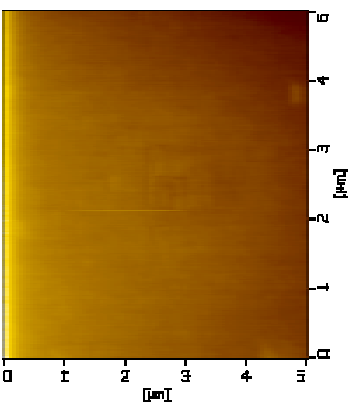

High homogeneity
BGST 10\%

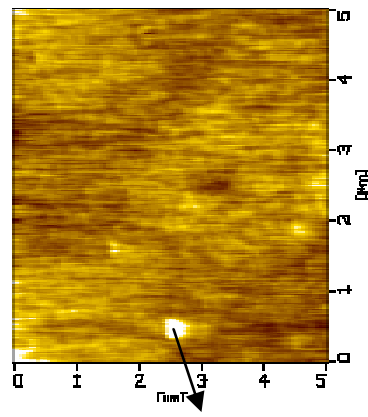

Peak seen as white spot

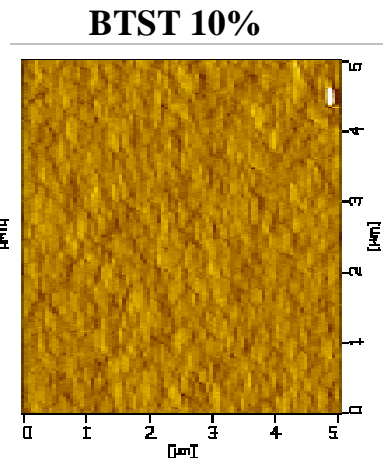

High roughness

\section{RMS roughness \\ $=10.50 \mathrm{~nm}$}

RMS roughness

$=0.2202 \mathrm{~nm}$

Figure 1. Surface analysis using AFM method at $200^{\circ} \mathrm{C}$ of $5000 \mathrm{~nm} \times 5000 \mathrm{~nm}$ area for BST, BGST, BTST thin films.

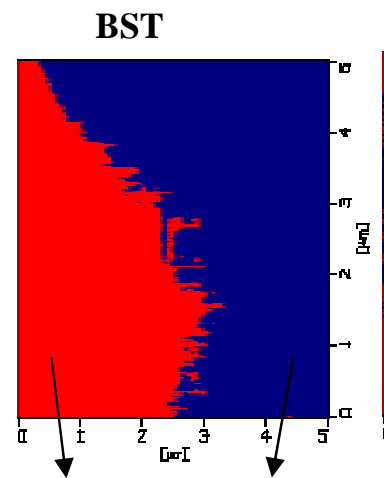

High altidude Low altitude/ /thickness (red) thickness (blue)

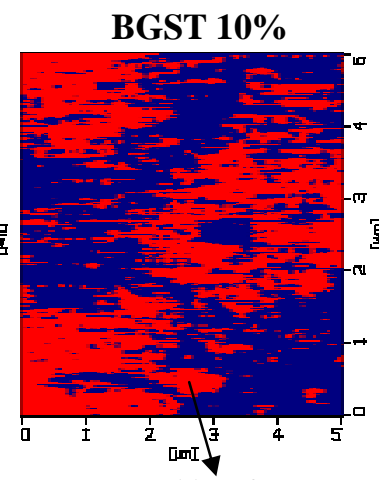

Position of peak

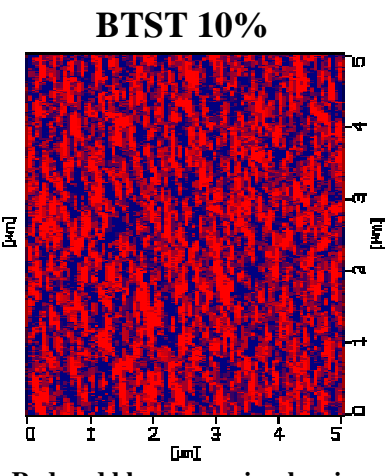

Red and blue area mix, showing clear case of roughness

Mean size $=15680 \mathrm{~nm}^{2}$

Mean diameter $=141.3 \mathrm{~nm}$

Figure 2. Grain analysis using AFM method at $200^{\circ} \mathrm{C}$ of $5000 \mathrm{~nm} \times 5000 \mathrm{~nm}$ area for BST, BGST, BTST thin films. 


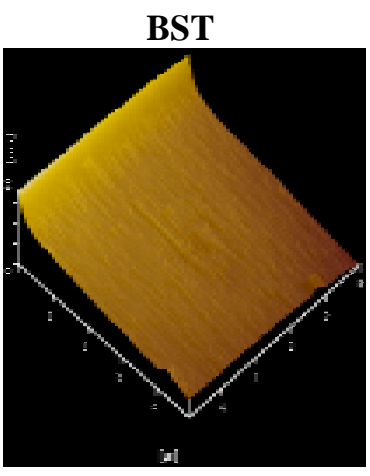

$$
\begin{aligned}
& \varnothing=45^{\circ} \\
& \Theta=30^{\circ}
\end{aligned}
$$

Mean size $=858600 \mathrm{~nm}^{2}$ Mean diameter $=1046 \mathrm{~nm}$
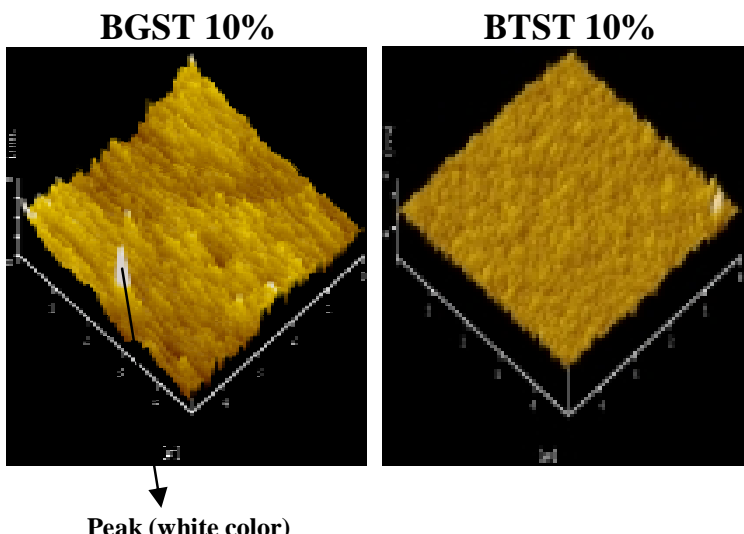

Peak (white color)

$$
\begin{array}{ll}
\varnothing=45^{\circ} & \varnothing=45^{\circ} \\
\Theta=30^{\circ} & \Theta=30^{\circ}
\end{array}
$$

Mean size $=44650 \mathrm{~nm}^{2} \quad$ Mean size $=15680 \mathrm{~nm}^{2}$ Mean diameter $=238.4 \mathrm{~nm}$ Mean diameter $=141.3 \mathrm{~nm}$

Figure 3. The 3 dimension analysis using AFM method at $200^{\circ} \mathrm{C}$ of $5000 \mathrm{~nm}$ $\mathrm{x} 5000 \mathrm{~nm}$ area for BST, BGST, BTST thin films.

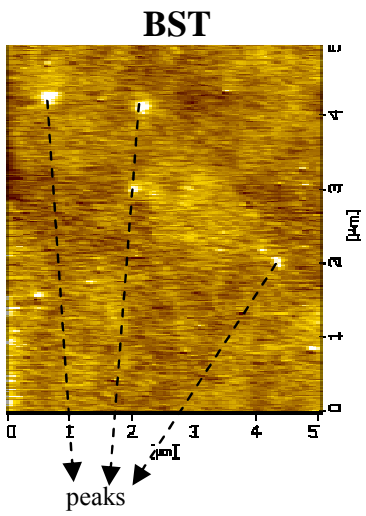

RMS roughness $=0.7902 \mathrm{~nm}$

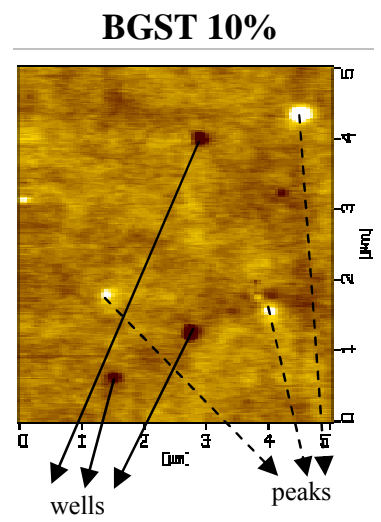

RMS roughness $=0.5641 \mathrm{~nm}$
BTST 10\%

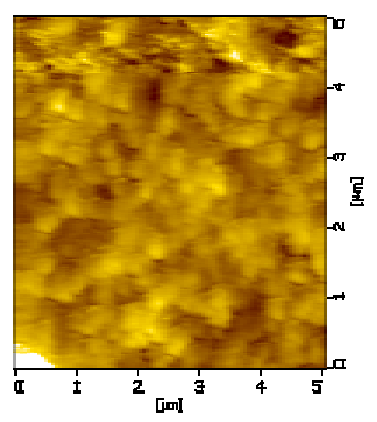

RMS roughness

$=0.2222 \mathrm{~nm}$

Figure 4. Surface analysis using AFM method at $240^{\circ} \mathrm{C}$ of $5000 \mathrm{~nm} \mathrm{x}$ $5000 \mathrm{~nm}$ area for BST, BGST, BTST thin films. 
BST

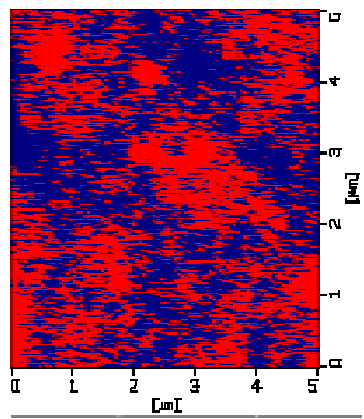

Mixing of red and blue areas, blurred distribution

Mean size $=19780 \mathrm{~nm}^{2}$

Mean diameter $=158.7 \mathrm{~nm}$

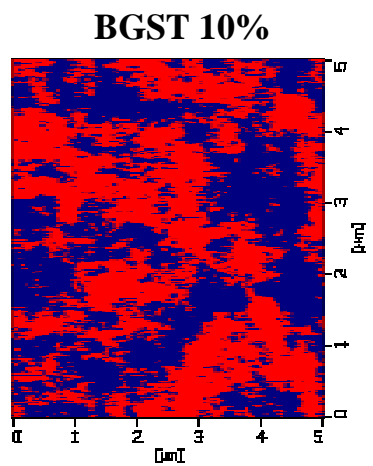

Mixing of red and blue areas, less grouped

Mean size $=256410 \mathrm{~nm}^{2}$

Mean diameter $=291.1 \mathrm{~nm}$

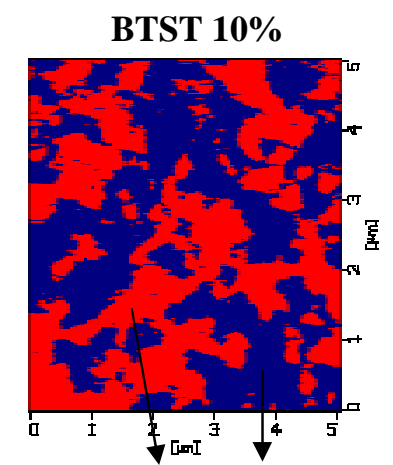

Mixing of red and blue areas, but more grouped

Mean size $=123600 \mathrm{~nm}^{2}$

Mean diameter $=396.7 \mathrm{~nm}$

Figure 5. Grain analysis using AFM method at $240^{\circ} \mathrm{C}$ of $5000 \mathrm{~nm}$ x $5000 \mathrm{~nm}$ area for BST, BGST, BTST thin films.

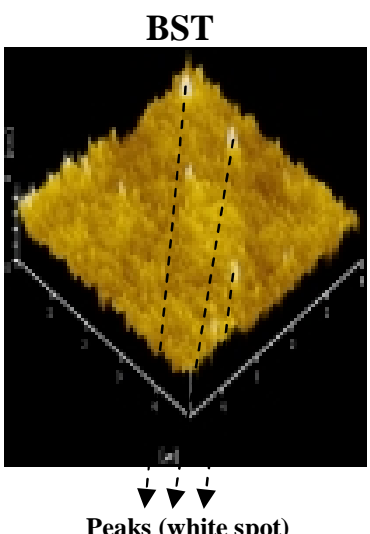

Peaks (white spot)

$$
\begin{aligned}
& \varnothing=45^{\circ} \\
& \Theta=30^{\circ}
\end{aligned}
$$

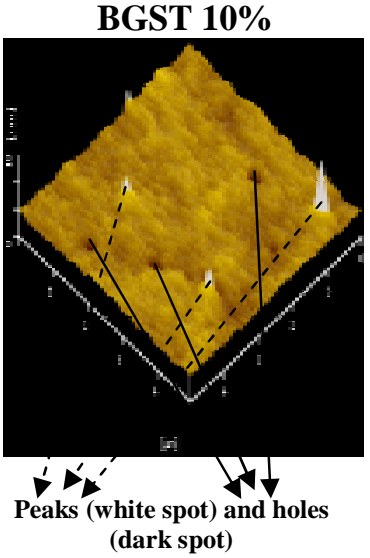

$$
\begin{aligned}
& \varnothing=45^{\circ} \\
& \Theta=30^{\circ}
\end{aligned}
$$

BTST $10 \%$

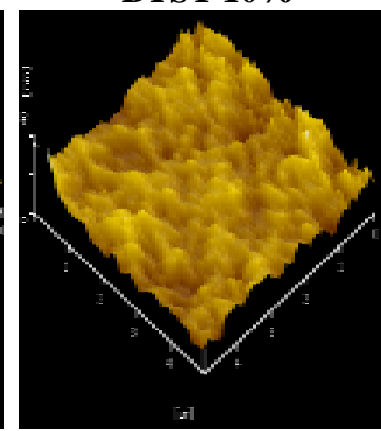

No peaks nor holes

$$
\begin{aligned}
& \varnothing=45^{\circ} \\
& \Theta=30^{\circ}
\end{aligned}
$$

Figure 6. The 3 dimension analysis using AFM method at $240^{\circ} \mathrm{C}$ of $5000 \mathrm{~nm}$ x $5000 \mathrm{~nm}$ area for BST, BGST, BTST thin films. 
BST

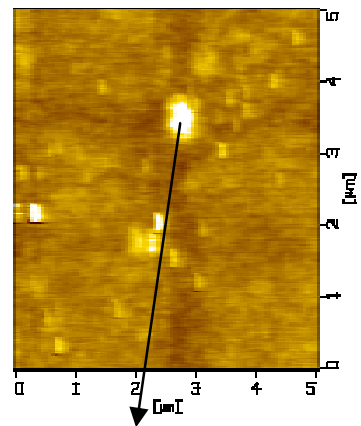

Big peak (white spot).

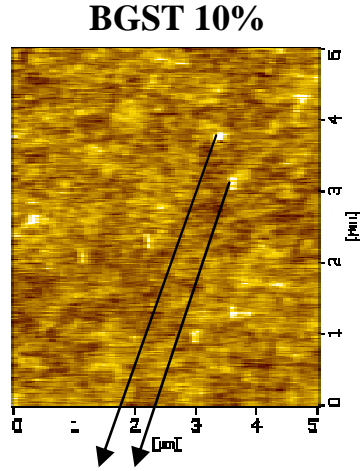

Small blurred peaks

RMS roughness

$=0.4870 \mathrm{~nm}$
BTST 10\%

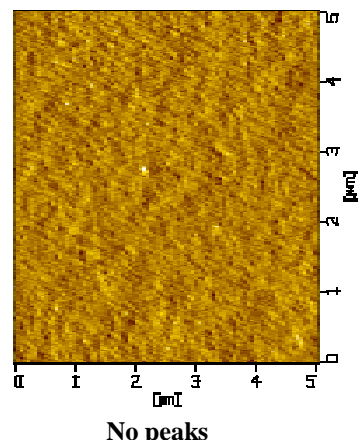

RMS roughness

$=0.2317 \mathrm{~nm}$

Figure 7. Surface analysis using AFM method at $280^{\circ} \mathrm{C}$ of $5000 \mathrm{~nm}$ x $5000 \mathrm{~nm}$ area for BST, BGST, BTST thin films.

BST

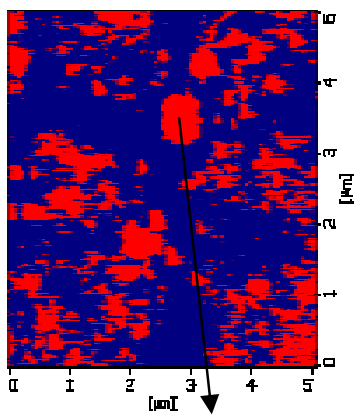

Big peak (red).
BGST 10\%

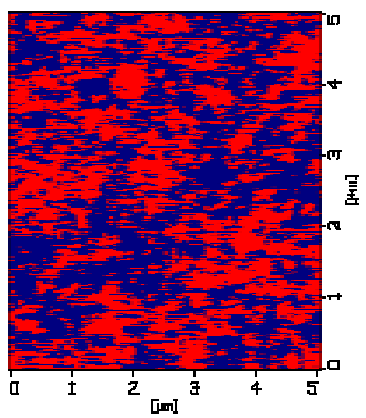

Mean size $=256410 \mathrm{~nm}^{2}$

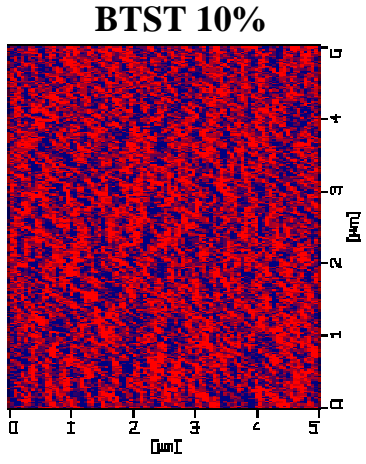

Smooth mixture between red and blue area

Mean size $=123600 \mathrm{~nm}^{2}$

Mean diameter $=396.7 \mathrm{~nm}$

\section{Mean diameter $=158.7 \mathrm{~nm}$ Mean diameter $=291.1 \mathrm{~nm}$}

Figure 8. Grain analysis using AFM method at $280^{\circ} \mathrm{C}$ of $5000 \mathrm{~nm} \times 5000 \mathrm{~nm}$ area for BST, BGST, BTST thin films. 


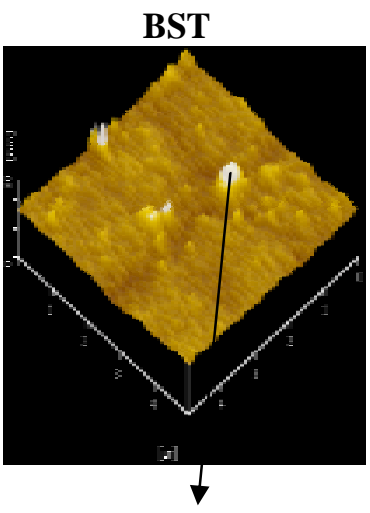

Big peak

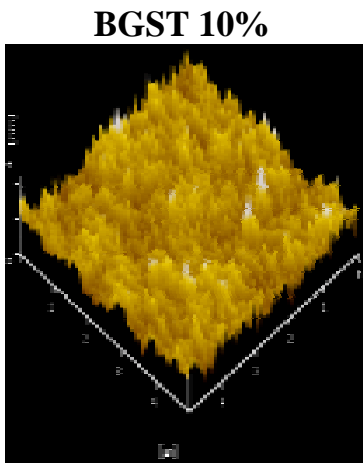

Peaks and higher roughness

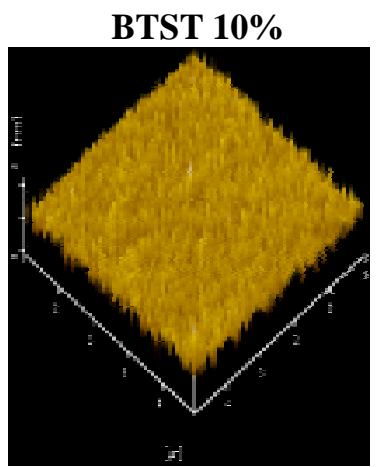

Smooth mixing roughness (no single peaks)
$\varnothing=45^{\circ}$
$\varnothing=45^{\circ}$
$\varnothing=45^{\circ}$
$\Theta=30^{\circ}$
$\Theta=30^{\circ}$
$\Theta=30^{\circ}$

Figure 9. The 3 dimension analysis using AFM method at $280^{\circ} \mathrm{C}$ of $5000 \mathrm{~nm}$ x $5000 \mathrm{~nm}$ area for BST, BGST, BTST thin films.

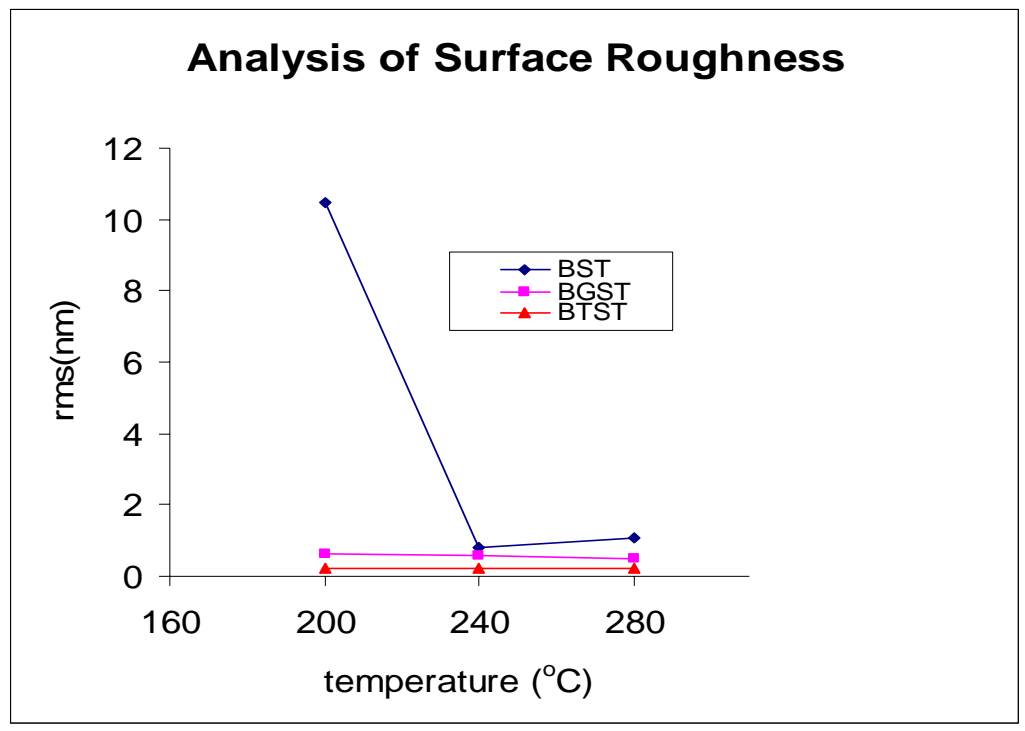

Figure 10. Graph of surface roughness varying annealing temperature. 


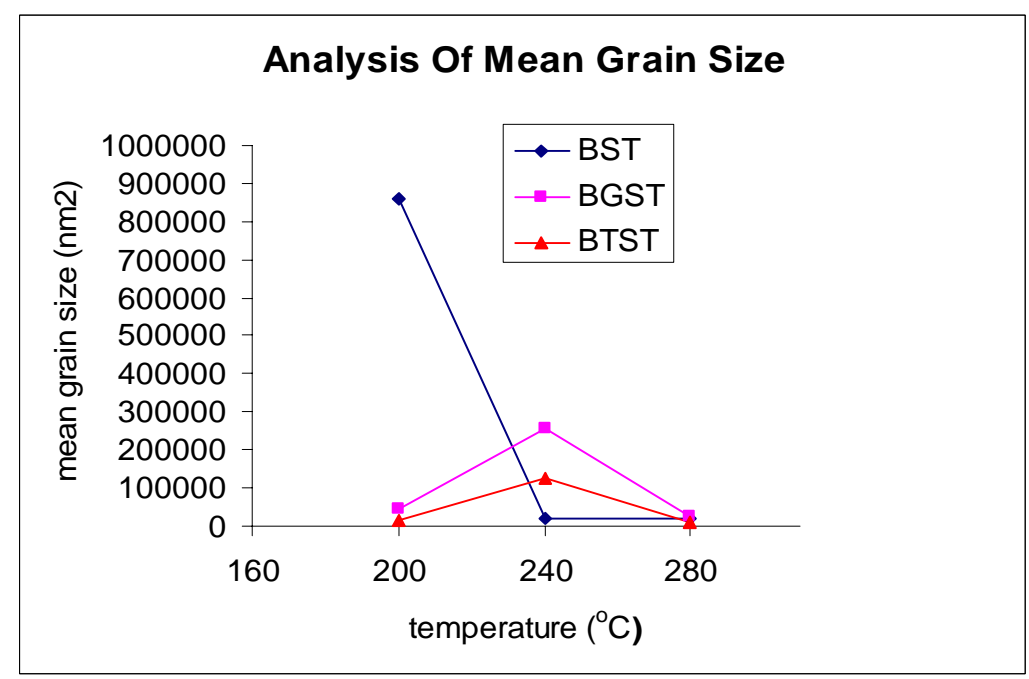

Figure 11. Graph of mean grain size varying annealing temperature.

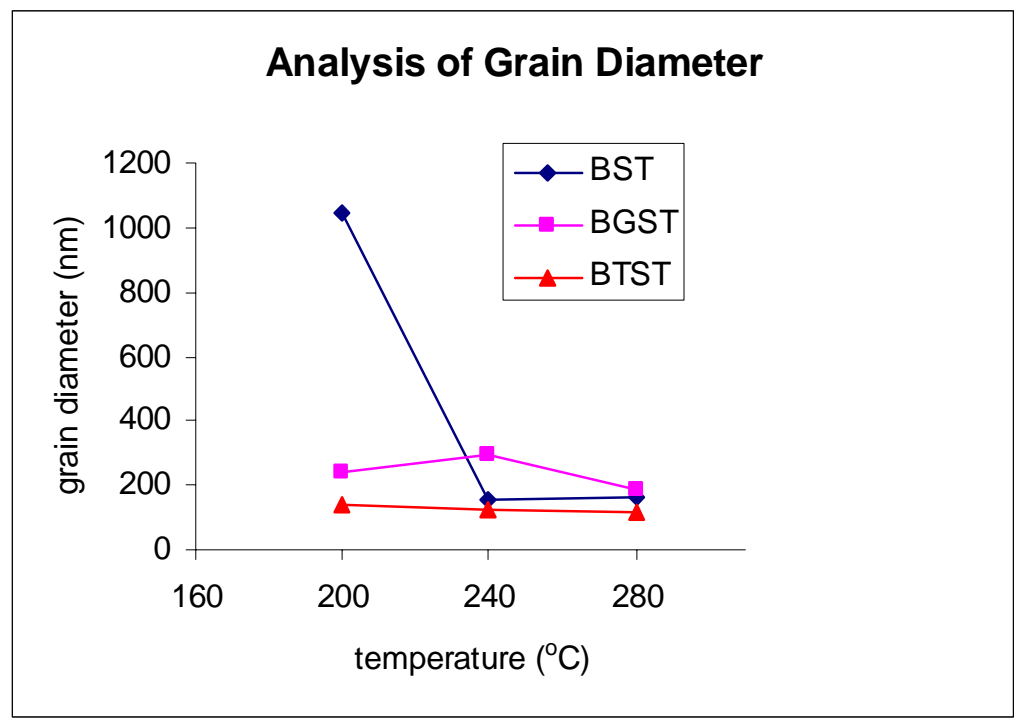

Figure 12. Graph of grain diameter varying annealing temperature. 
In ferroelectric fenomenon, acceptor doping gallium oxide doped barium strontium titanate is more likely very effective for generating movable dipoles and domain pinning, since the oxygen ions are still movable even below the Curie temperature (e.g. at room temperature), because the oxygen and vacancy adjacent (only $2.8 \AA$ ) and hopping easily occurs, on the other hand donor doping tantalum oxide doped barium strontium titanate is not more likely very effective for generating movable dipoles and domain pinning, since the $\mathrm{Ba}$ ion or $\mathrm{Sr}$ ion cannot easily hop to an adjacent A-site vacancy due to the close oxygen $(\mathrm{O})$ surroundings [22].

\section{CONCLUSION}

We have investigated the annealing temperature of BST, BGST and BTST thin films deposited by the chemical solution deposition (CSD) method with spinning speed at $3000 \mathrm{rpm}$ for 30 seconds. The post annealing at $200^{\circ} \mathrm{C}, 240^{\circ} \mathrm{C}, 280^{\circ} \mathrm{C}$ for 1 hour were carried out to each deposited film. In fact, to increase annealing temperature from $200^{\circ} \mathrm{C}$ to $280^{\circ} \mathrm{C}$ would result in decreasing the rms roughness and grain size. Therefore, rms roughness and grain size would have the strong correlation annealing temperature.

\section{ACKNOWLEDGEMENTS}

This work was supported by Program Hibah Kompetitif Penelitian Unggulan Strategis Nasional 2009, Dikti, The Republic of Indonesia under contract no. 413/SP2H/PP/DP2M/VI/2009 and Short Term Research Grant from Northern Malaysia University College of Engineering, Malaysia under contract No. KUKUM/R\&D/9003-00030(1)/2005.

\section{REFERENCES}

1. B.A. BAUMERT, L.H. CHANG, A.T. MATSUDA and C.J. TRACY., J. Mater. Res., 13 (1) 197 (1998).

2. F. WANG, A. UUSIMAKI, S. LEPPAVUORI, S.F. KARMANENKO, A.I. DEDYK, V.I. SAKHAROV, I.T. SERENKOV., J. Mater. Res., 13 (5) 1243 (1998).

3. J.G. CHENG, J.TANG, J.H. CHU, A.J. ZHANG., Appl. Phys. Lett., 77, (7) (2000) 1035.

4. M.A. ITSKOVSKY., Jpn. J. Appl. Phys., 38 (8) 4812 (1999).

5. E.S. CHOI, J.C. LEE, J.S. HWANG, S.G. YOON., Jpn. J. Appl. Phys., 38 (9B) 5317 (1999). 
6. Y. GAO, S. HE, M. ENGELHARD, A.S. LEA, J. FINDER, B. MELNICK, R.L. HANCE., J. Appl. Phys., 87 (1) 124 (2000).

7. S. MOMOSE, T. NAKAMURA, K. TACHIBANA. Jpn. J. Appl. Phys., 39 (9B) 5384 (2000).

8. M. IZUHA, K. ADE, M. KOIKE, S. TAKENO, N. FUKUSHIMA., Appl. Phys. Lett., 70 (11) 1405 (1997).

9. T. KAWAKUBO, K. ABE, S. KOMATSU, K. SANO, N. YANASE, H. MOCHIZUKI., IEEE Electron Device Letters, 18 (11) 529 (1997).

10. S.Y. CHA, B.T. JANG, H.C. LEE., Jpn. J. Appl. Phys., 38 (1A) L49 (1999).

11. B.T. LEE, W.D. KIM, K.H. LEE, H.J. LIM., Journal of Electronic Materials, 28 (4) L9 (1999).

12. J.C. SHIN, J. PARK, C.S. HWANG, H.J. KIM. J. Appl. Phys., 86 (1) 506 (1999).

13. J.S. LEE, J.S. PARK, J.S. KIM, J.H. LEE, Y.H. LEE, S.R. HAHN., Jpn. J. Appl. Phys., 38 (5B) L574 (1999).

14. S. KIM, T.S. KANG, J.H. JE., J. Mater. Res., 14 (7) 2905 (1999).

15. I. RATERA, J. CHEN1, A MURPHY, D.F. OGLETREE1, J.M.J. FR'ECHET and M. SALMERON., Nanotechnology, 16, S235 (2005).

16. D. DIETZEL, M. FAUCHER, A. IAIA, J. PAIM'E, S. MARSAUDON, A. M. BONNOT, V. BOUCHIAT AND G. COUTURIER., Nanotechnology, 16, S73 (2005).

17. B.A. LONG, S.H.U. JIAN, S.U.N. PING, L.U. ZU-HONG., Chin. Phys. Lett., 20 (4) 465 (2003).

18. N.S. TAMBE and B. BHUSHAN., J. Phys. D: Appl. Phys., 38, 764-773 (2005).

19. M. ABE, Y. SUGIMOTO, O. CUSTANCE and SEIZO MORITA., Nanotechnology, 16, 3029-3034 (2005).

20. A.W. SPARKS and S.R. MANALIS., Nanotechnology 17, 1574-1579 (2006).

21. P.D. SAWANT, and D V NICOLAU., Smart Mater. Struct. 15, S99-S103 (2006).

22. K. UCHINO., :'Ferroelectric Devices", Marcel Dekker, Inc. New York, 131 (2000). 